\title{
Europe and the Middle East: From Imperialism to Liberal Peace?
}

\author{
Raymond Hinnebusch ${ }^{1}$ \\ ${ }^{1}$ School of International Relations, University of St Andrews, Scotland, UK \\ Correspondence: Raymond Hinnebusch, School of International Relations, University of St Andrews, St \\ Andrews, Fife KY16 9AX, Scotland, UK. Tel: 44-1334-462-861. E-mail: rh10@st-andrews.ac.uk
}

Received: November 24, 2011 Accepted: April 26, 2012 Online Published: July 1, 2012

doi: $10.5539 /$ res.v4n3p18

URL: http://dx.doi.org/10.5539/res.v4n3p18

\begin{abstract}
Europe's relation with the Middle East and North Africa (MENA) is discussed in the context of normative (International Society) and materialist approaches (World System's Theory). First, European imperialism's export of a flawed Westphalian state system is summarized. How Europe is "caught" between MENA and the US and co-opted into a division of labour toward the region is then surveyed. The gap between the normative rhetoric and actual inequitable outcomes and structures constructed under the Euro-Mediterranean partnership is examined, looking at the three "baskets" of economic developmental, political reform and cultural convergence. Four "hard cases," EU policies toward Palestine, Iran, Syria and Turkey, illustrate the ambiguities of the EU's approach to MENA. MENA public opinion's ambivalence toward Europe reflects these realities. The conclusion is that the EU'sMENA policy is caught between the rhetoric of post-colonialism and practices of neo-colonialism.
\end{abstract}

Keywords: EU, Middle East, Euro-Mediterranean partnership, neo-liberalism

\section{Introduction}

Europe literally made the contemporary Middle East states system. International society approaches stress the export of institutions and norms, notably the modern nation-state, from the European core. As Little and Buzan (2009) pointed out, however, the expansion of European international society took place first through conquest and only secondly via the diffusion and internalization of Western ideas of nationalism and sovereignty, and then de-colonization. For World Systems Theory, moreover, imperialism's incorporation of the Middle East into the world economic periphery largely survived de-colonization. In its current self-image, Europe's relations with the Middle East have moved from imperialism to soft power, the export of its norms by the force of example, distinguishable from the deployment of hard power in the region by the US hegemon. According to Adler and Crawford (2004), "The Barcelona Process is a laboratory where one of the most outstanding experiments in international relations may have started to take place," namely an attempt to turn the "clash of civilizations" recently provoked by US hard power into a convergence of civilizations.

There is, however, a certain gap between Europe's benign self-image and its image in the Middle East. Europe's self-image might be seen as a legitimizing "superstructure" that fits only imperfectly with the unequal material structure of power relations between it and MENA. More than that, Clark sees contemporary neo-liberal globalization, of which the EU has become an agent, as a project by the core to claw back the concessions of de-colonization and create an international society of only semi-sovereign states of a uniform liberal type. What does the evidence tell us?

\section{Europe and the Making of the Middle East}

The Middle East has been profoundly shaped by the historic expansion of European imperialism into the region, beginning with its encroachment on the Ottoman Empire. This encounter set off debates in both West and East. If in the West the Eastern Question was framed in terms of the decline of the Ottoman "Sick Man of Europe," supposedly owing to "Oriental despotism" or Islam's resistance to innovation, in MENA the result was a parallel debate over the West's impact and how to respond to it (Valbjorn 2011), as detailed in a wealth of classic studies (e.g. Hourani 1963). Westernizers argued for defensive modernization: MENA countries could only retain their independence and join the modern world via Westernization, including secularization, a view evident in Rifa 
al-Tahtawi, Ali Abdal-Raziq and liberal Egyptian nationalism but which reached its apogee in Ataturk's Turkey. A second argument insisted that MENA's weakness was due precisely to Westernization, a deviation from God's path, and advocated a return to the practices of Islam's golden age under the rightly-guided Caliphs; the current Saudi state is the product of one such movement, the Wahhabis. The more common middle position argued for selective borrowing from the West, adopting its techniques of power, such as military and bureaucratic modernization and industrialization, while preserving the region's Islamic culture, although within this tendency there were multiple divergences over issues such as capitalism and socialism and the territorial state vs. the larger umma.

Parallel to such debates, Western imperialism's material power proved irresistible, territorially conquering the whole region, with two exceptions, which ironically represented the two extreme cases in the debate, Ataturk's Turkey and Wahhabi Arabia. Throughout the Arab world, the imperial powers defeated indigenous armies and insurgencies using artillery and aerial bombardment of cities, villages and tribes.To give local elites a stake in the imperial order, the metropoles encouraged their private appropriation of the collective patrimony-land, oil-thus turning tribal and mercantile notables into great landlords or rich rentiers and tribesman and peasants into agricultural proletariats. Minorities were regularly co-opted and armed, thereby alienating them from the majority and making them dependent on the imperial powers. There was little large-scale non-indigenous settlement in the region but where it did take place, in Palestine and Algeria, the indigenous population was dispossessed, in the former case, permanently. Simmering resistance, never definitively subdued, revived in the form of mass independence movements and revolts every time Western control seemed to falter, e.g. in WWII when France and Britain faced defeat by Germany (Adelson 1995; Khalidi 2004: 1-36, Fromkin 1989: 449-54).

In what was seen by Arabs as a divide and rule strategy, European imperialism permanently fragmented the region into a multitude of weak and insecure states inevitably dependent on Western protectors even after independence. The arbitrary boundary drawing by which Britain and France divided the Arabic speaking world among themselves, reflective of their own interests and compromises and in defiance of indigenous wishes, grossly violated regional identity. It issued in somewhat artificial states that struggled to command the identifications of their populations which tended to remain with the small sub-state (tribes, sects) or supra state units - the Islamic umma and the imagined Arab nation. The most obvious exception and one of the few relatively strong states in the region was Turkey, where Ataturk almost uniquely was able to fight off imperialism, hence establish borders for an independent state compatible with the idea of a Turkish nation and with enough legitimacy to later democratize.

Arbitrary boundary drawing also built conflict into the very fabric of the regional states system. Consequent border conflicts generated durable centres of regional war-in the Gulf, notably over the Shatt al-Arab, between Algeria and Morocco and between Israel and its neighbours. The creation of Kuwait blocking Iraq's access to the Gulf also meant drawing a line around oil wells and creating an artificially privileged population bound to excite the envy of its stronger neighbour. Arbitrary boundaries, cutting across identities, frustrated Arab nationalism and Kurdish nationhood. Israel, a colonial settler state established under British auspices in the heart of the region at the expense of indigenous people, was bound to be rejected; yet its unmatched network of strategic depth in the West made it the dominant regional military power, allowing it to extend its colonization at the expense of the Palestinians, who, a state-less people, became an intense source of irredentism, and to occupy the territory of neighbouring states.

Imperial takeover consolidated the incorporation of the region into a global economic division of labour, a process begun through the imposition of unequal treaties on the Ottomans and completed after Western conquest by the break-up of the large Ottoman market, snapping regional interdependencies, and reorienting economic links to the imperial core. The role of MENA colonies was to supply raw materials to and serve as markets for Western industries, at the expense of local artisanal industries. The concentration of much of the oil wealth in tiny client states ensured those countries exported capital surpluses to the West while larger states with the land and labour potential for diversified economies lacked capital. Western powers did everything they could to prevent the region from taking command of its oil resources, beginning with the 1953 overthrow of Iran's Mossadeq. In the post-imperialist era, European countries continued commercial competition in the region, selling, in particular, arms to insecure oil-rich mini-states, thus facilitating the recycling of petro-wealth back to Europe (Alnasrawi 55-66, 191-93; Owen 1981: 3-9, 92)

European empires constituted the regimes that would inherit power after independence, but in very flawed ways.As elsewhere, imperialism generated its antithesis, nationalism--the more intense the longer the struggle for independence and the less complete the outcome. Formally liberal political institutions were established but could not be consolidated because the co-opted elites that dominated them constituted an oligarchy of 
imperial-fostered landlords and tribal chiefs whose clientele networks and biased electoral systems kept the middle classes excluded and the masses unmobilized. Hence, the military elites trained under imperialism almost everywhere assumed power after independence. In reaction against the inegalitarian heritage of European rule, radical officers led waves of revolutions that gave birth to populist authoritarian regimes in the more developed Arab lands; beginning with Nasser's Egypt and rapidly spreading elsewhere, they seemed to mark a profound rupture with the age of imperialism. However, the exhaustion of statist development and the end of the Cold War forced them into economic openings that made them again vulnerable to penetration by the core powers and to neo-liberal discourse that would shift the balance of elite opinion toward Westernizers. In the most tribal parts of the Arab world, where protectorates froze existent social structures and growing oil resources energized an effective clientalism, British imperialism engineered an anomaly in the modern world, ruling monarchy.

The post-independence recognition of the sovereignty of MENA states by "international society" was embraced by the elites that inherited power after the retreat of European empires, as a protection against stronger neighbours and interference by the ex-empires, although initially with reluctance and ambivalence by would-be regional hegemons and public opinion insofar as sovereignty sanctified artificial boundaries at the expense of Pan-Arab identity. Even as direct European colonialism came to an end, the West attempted to organise a post-imperial treaty system, the Baghdad Pact, later supplemented by the Eisenhower Doctrine, that would preserve their military bases and influence, ostensibly against communism, but in practice also against Arab nationalism. The Suez war in which Britain and France, together with Israel, tried to defeat Egypt's Nasser, the standard-bearer of Arab nationalism that had effectively defied the Baghdad Pact, led to Europe's political recession from the region, culminating in Britain's 1974 military withdrawal from the Gulf. This left, from the viewpoint of the West, a "vacuum" which the US gradually begin to fill, partly through alliances with conservative and/or non-Arab states, the Shah's Iran, Turkey and Israel, against the Arab nationalist states, partly thorough a creeping military presence in the Gulf.

Continuing Western interference in the region only kept anti-imperialist nationalism alive. Yet, attempts to restructure core-periphery relations, such as Egypt's brief Pan-Arab hegemony and Iran's Islamic revolution, all failed to establish a viable alternative order: the residues of the Western imperial era-borders, client elites, inter-regional conflicts, Israel - combined with external intervention and the continued incorporation of the oil-rich part of the region into core economic networks, blocked such projects and instead resulted, especially since the end of the Cold War, in growing US hegemony over the region; it established a protectorate over the Arab Gulf states after the Gulf war of 1990-91 and, in a return to the practices of high imperialism, conquered Iraq in 2003.

Thus, the Middle East, as Brown (1984) argues, remains the most penetrated Third world region and is, as Buzan (1991) observes, the one classical civilization that has not recovered its historical greatness after European empire, in part because of the destruction of the large Ottoman market that could otherwise have formed the basis of post-independence economic recovery as happened in China and India where the pre-capitalist empires survived. According to Lustik (1997), there are no Middle East great powers because no indigenous actor is allowed to expand by challenging artificial boundaries in the name of Pan-Arab empire or Islamic revolution, as Saddam's Iraq discovered. This is the historical reality against which Europe's post-imperial project in the region has taken shape.

The permanently damaging effects of imperialism explains whyMENA is the third world region where anti-imperialism remains strongest and why external hegemony, lacking legitimacy, continues to stimulate resistance, keeping the region unstable. The debate in the region over how to cope with the West remains the single most powerful axis around which regional politics revolves. The secular nationalist solutions, such as Nasserism and Ba'thism, had represented the middle ground, adopting Western models of material modernization precisely in order to resist and compete with the West. Their failure threatened to polarize the region between the extremes, at the elite level new Westernizers, taking command of the authoritarian regimes inherited from the nationalist period, and at the mass level, opposition Islamists, expressive of the drive to return to the "right path." Possibly bridging this polarity is a new middle formula, liberal variants of Islam, represented by Turkey's AKP, that appear compatible with an indigenous form of democratic capitalism, capable of bridging the civilizational divide between Europe and MENA.

\section{Europe "Caught" between MENA and the US—or a Division of Labour?}

MENA-EU relations cannot be discussed without reference to the US, which, as Nonneman argues, is part of a triangular relationship, with the Western powers combining competition and cooperation in MENA. As decolonization proceeded and Europe's dominance of the region ended, the US filled what was seen as a vacuum, 
although North Africa remained more closely tied to Europe. While withdrawing politically from the region, Europe retained economic and energy interests there, sought amicable commercial relations with all states, and tried to avoid making enemies, with some European states periodically disassociating themselves from US military actions such as Reagan's 1986bombing of Libya.

The US used periodic crises in MENA to reinforce its hegemony over Europe. This was recharged when, after the 1970s oil crisis, Washington established a strategic alliance with Saudi Arabia, the swing producer on the global petroleum market and with the world's largest energy reserves. The US and Europe both needed to enhance their trade with the region to pay for much more expensive oil imports. However, the US engineered the recycling of the vast surplus petrodollars of the main Gulf oil producers, not thru the IMF as Europe wished, but through US private banks as well as arms sales to the oil exporting states. The Gulf states became conduits for the transmission of the huge revenues paid for imported oil by the whole world to Wall Street and to a lesser extent to City of London financial institutions. This bolstered America's competitive advantage over Europe and was also a factor in empowering Anglo-American finance capital's dominance over productive capitals in Europe in the subsequent period of financial "globalization" (Spiro 1999).

The UK's withdrawal East of Suez and growing US intervention from the time of the Iran-Iraq war gradually established a US protectorate over the Gulf. In the 1990 Gulf war and parallel with the end of the Cold war, Europe found pressures to bandwagon with Washington irresistible. After the war, US arms, oil and construction companies took the lion's share of sales to the Arab Gulf and Washington used sanctions to force its economic competitors to give up their economic stake in Saddam's Iraq, which the US expected to inherit after invading Iraq in 2003 (although it has not quite worked out this way). The US also used extra-territorial laws and the construction of UN sanctions regimesto deter European countries from relations with Iran. Thus, Washington tired to deny its economic competitors access to the main energy fields not controlled by US companies or client states (Marr 1998: 85-8, 94).

As Washington sees it, while Europe depends more heavily on MENA for trade and energy, America's military power provides regional security and protection of oil supply routes, entitling it to demand European compliance with its regional policies (Marr 1998). Many in Europe, however, see US policy as counterproductive in that it stimulates the crises from which it then acts to protect its allies. Yet Europe is unable to alter US policy. Indeed, the EU lacks the cohesion to act as a unified actor in key MENA crises vis-à-vis the US, as was brutally exposed by its division over the 2003 Iraq war. The harsh US response to French and German defiance in this instance made Europe more reluctant to again challenge the US. The war was damaging for the EU: not only did it make a shambles of Europe's common foreign and defense policy, but regime change in Iraq, ostensibly to precipitate democratic spillover, actually generated widespread insecurity that drove MENA regimes to heighten internal repression in the name of anti-terrorism and to diversify their relations toward Asia, rather than open up and embrace the soft power formula of the EU. Europe is seemingly "caught," according to Salame (1998), between MENA and the US.

Unable to act independent of the US, yet vulnerable to the "blowback" of US policy, Europe has had to accept a division of labour with the US regarding the region. Washington uses its unmatched "hard" military power to intimidate or intervene against defiant regional states while the EU deploys its soft power and economic prowess. NATO, which links them, has expanded its remit to MENA, drawing Europe into American occupation regimes in Iraq and Afghanistan and enlisting it in the US war on terror. Seen as a war on Islam in Middle East public opinion, this interventionism arguably deepens "blowback" which then drives the US and Europe closer together over the threats of terrorism and nuclear proliferation (Schumacher 2010). At the economic level, the two also share an interest in promoting neo-liberalism and similarly deploy a combination of incentives, pressures and surveillance to force MENA states to open their economies to Western capitalist penetration, collaborating in some ways as a "collective hegemon" to extend the structural power of core capital over the periphery (Holden 2010: 15; Cavatorta and Durac 2010: 8).

\section{Europe and Post-Independence MENA: The Euro-Mediterranean Partnership}

As the EU gradually came into being as a collective actor with its own identity, its ambition to reassert Europe's influence independent of Washington, especially over its MENA near neighbourhood, increased. The EU aimed both to enhance its economic advantages in the area against competitors and also to stabilize the region by projecting "normative" power, exporting, thorough the power of attraction, its Kantian model (Tonra and Cavatorta 2007; Youngs 2004).

The new European approach was embodied in the Euro-Mediterranean Partnership (EMP) launched by the 1995 Barcelona Declaration between Europe and southern Mediterranean states, with the aim of transforming the 
Mediterranean region into an area of peace and stability based on principles of human rights and democracy and on shared prosperity. The latter was to be generated through establishment by 2010 of a cross-regional free trade zone. In the EU's liberal paradigm, inter-regional trade was expected to generate shared interests in peace and prosperity that would dilute radicalism and conflict. Also involved was an attempt, through dialogue and the power of attraction, to construct an imaginary new Mediterranean identity that would subsume cultural differences between the EU and MENA and head off a clash of civilization. Security challenges emanating from the southern Mediterranean were seen as deriving less from hostility or military threats than from economic and political failures in MENA that could be pre-empted through socio-economic strategies in cooperation with MENA countries (Youngs 2003)

The EU's motives for the Barcelona process were, however, more self-interested than its rhetoric suggested. Lacking hard power, Europe had no option but to try to build shared interests with MENA partners to protect its interests. The 1970s Euro-Arab Dialogue, the precursor of the EMP, had been a response to the 1970's oil crisis that threatened European economies. Energy security has continued to be central to European relations with MENA: in 1995 of the 9.6 million bpd of oil imported by Europe 5.5 (57\%) came from MENA and half of this from the Gulf (Marr 1998; Hollis 1997; Holden 2010). Several immediate threats stimulated the EMP initiative in the mid-90s: the need to head off a trade war when Morocco retaliated against European aid suspension by cancelling access to its fishing waters for EU boats (Joffe 1998) and alarm at the anti-Westernism aroused in the south of the Mediterranean by the Gulf war both called for some response. The failed Algerian transition to democracy precipitated European fears of a spill-over of instability to the north: failed states, stagnant economies and civil wars were seen as a source of refugee flows, drug trafficking, and especially after 11 September 2001, of terrorism. The spread of radical Islam among Muslim communities in Europe became a particular preoccupation. Geographical proximity exposed Europe to flows of migrants from its southern Mediterranean neighbourhood, likely to greatly increase if growing youth unemployment in the region was not addressed thorough economic development; some 3.6 million migrants had already come from Morocco (2.1 million), Algeria (1.5 million), Tunisia (0.4 million), Egypt (0.2 million) and Syria (0.18 million) (Le Monde, 12.7.2008) and the EU sought to secure the cooperation of MENA governments in containing such flows.

Scholars have identified numerous flaws in the EMP. For Dostal (2009), the underlying problem is the EU's adoption and export of neo-liberal ideology. The EU genuinely wants economic development, seen as essential to head off migration and instability in the MENA, but the uncontested hegemony of neo-liberal ideology inside the EU, with its stress on a market that favours corporations at the expense of the Social Charter, a reflection, Grahl (2004) argues, of the dominance of business interests, is naturally replicated in EU external policy toward MENA. In practice, therefore, the EMP became an instrument for the diffusion of neoliberal restructuring to MENA, reinforcing pressures from international financial institutions such as the IMF and WTO.

While the EMP was supposed to generate prosperity in the partner nations, in the immediate term, it actually worsened the conditions of trade for MENA (Joffe 1998: 66-68). Europe's trade agreements with MENA states in the pre-neo-liberal 1970s had granted them preferential access to European markets for some of their industrial and agricultural products, although the EU would regularly enforce quotas whenever Egyptian cotton, Gulf petrochemicals, Turkish textiles or Moroccan oranges threatened to enlarge their market shares (Salame 1998: 35). But crucially, MENA states were allowed, reflective of their lower levels of development, to protect their own industries. Current EMP agreements not only require the opening of MENA markets to European industrial exports (and those of Europe-based US multinationals) but also commits MENA countries to the global trade regime, e.g. on services and protection of intellectual property rights, that favours the north. The only improvement for MENA was slightly increased quotas for its agricultural exports (Miller and Mishraf 2005; Marks 1998; Parfitt 1997; Nienhaus, 1999).

The EMP gave MENA partner countries 12 years to dismantle their tariffs and accorded them financial aid to upgrade their industries so they could compete on the wider market and also to ease the balance of payment deficit that was expected in the transition period when European exports to the region would be more competitive than indigenous production. MENA economic takeoff would, it was argued, be facilitated by forcing its industries, through tariff reductions and technical assistance, to move from ISI to export strategies. The long term benefit, it was claimed, was that MENA states were required to adopt EU economic practices(such as greater administrative transparency, restructuring of the banking sector, the creation of an efficient tax and customs system, and improving the regulatory framework for small and medium-sized enterprises) that were expected to encourage investment in the region. Youngs (2003) argues that in practice, the EU, mindful of the potential for de-stablization has not pushed for hasty implementation of many of these provisions and has provided funds for social protection for the victims of the process. 
The outcome has been mixed. The elimination of tariffs and barriers for EU industrial exports has damaged MENA small and medium-sized businesses (60\% of Morocco's and 30\% of Tunisian's industries were not expected to withstand European competition) (Schumacher 2004). On the other hand, average MENA exports to the EU did increase from 28 to $33 \%$ of its total GDP from 1992 to 2002, indicative of some enhanced competitiveness. However, Europe's exports to the region have grown faster, at an annual average of 8 percent since the mid-1990s, an increase in export value of 250 percent between 1995 and 2007 (Schumacher 2010); the EU has run a trade surplus with its southern partners in the years since 2000.

As for investment, the EMP was expected to divert it to the EU since under the hub-and spokes arrangement, investors in the EU hub now get access to MENA partners, too (the spokes), while investing in the spokes would not give access to other spokes in the absence of a MENA free trade zone. While the EMP in principle encourages economic integration within MENA, and has been credited with inspiring the creation of the Greater Arab Free Trade Agreement, its hub and spokes character deters such integration. In fact, in the first decade of the EMP, FDI in MENA tripled. Part of this investment was, however, a one-off buying up of local, often privatized, assets, which will subsequently lead to a flow of repatriated profits back to Europe that might otherwise have remained in MENA. North Africa and the Gulf region together accounted for only 3 percent of European FDI outside the EU in 2003-2008 (Schumacher 2010: 13) Overall, gross fixed capital formation as a \% of GDP in the southern partner states declined from $25 \%$ in 1992 to $21 \%$ in 2002 as domestic private investment did not substitute for declining public sector spending, possibly discouraged by European competition (Michalek 2005). The income gap between the Mediterranean's northern and southern regions is still widening: in the first decade of the EMP, 1994-2005, the average income of the south as percentage of the north declined slightly to $18.1 \%$.

The EU has been separately negotiating trade agreements with the oil-rich Gulf countries but these have been stymied by Europe's unwillingness, under the influence of powerful EU energy companies, to open its energy market to downstream investments from Gulf states (as well as by disagreements over GCC unwillingness to liberalize procurement processes and EU attempts to include human rights clauses) (Schumacher 2004: 11; Schumacher 2010; Salame, 1998 35-6).

That North African governments (but not the oil rich Gulf states) have signed seemingly inequitable partnership agreements is in part due to asymmetric power relations. In trade terms, the MENA partners need Europe more than Europe needs them: while the region accounts for only around 5\% of Europe's trade (about double that for Spain, Italy and France), the MENA countries export from a quarter to three quarters (Morocco, Tunisia) of their products to Europe. Overall, 45\% of EU oil imports originated from the Middle East in 2007 but only 10\% from EMP partners, with the rest from the Gulf (although 30\% of its gas imports are from Algeria) (Euractiv 2007). Asymmetry is reflected, too, in the lower priority Europe assigned to the region compared to the accession of Eastern European countries. The EU negotiated agreements individually with each southern partner rather than collectively and separately from the Gulf countries, with their greater bargaining leverage; indeed, this very process embodied the reconstruction of a classic hub-and-spokes economic regime. This reflects not just the dominance of a unified core, but the fragmentation of the periphery countries which, producing similar low value added products, see each other as competitors and and sought privileged individual bargains with the EU.

The EMP has not, either, promoted democratization in MENA. Hyde-Price (2006) argues that the EU operates as a realist actor, promoting its interests irrespective of the values it espouses in principle; hence, primacy is given to the economic side of partnership agreements while democratization and human rights are neglected. Authoritarian regimes are needed to implement free trade agreements that pauperize MENA populations while democratization could bring radical Islamic movements to power (Tonra and Cavatorta 2007; Cavatorta and Durac 2010: 7-8). EU defenders claim it expects economic development to lead to democratization over the long run and that EU officials do better to encourage incremental political progress through dialogue and economic incentives rather than antagonizing regimes with predictably ineffective political demands (Manners 2002; Youngs 2003). This strategy would, however only be effective if neo-liberalism did lead to economic development; however, as Joffe (1998: 66-8) observes, no economy has ever developed under the economic openness the EMP mandates. Rather, its actual effect is to generate crony capitalism. Regimes use neo-liberal discourse and pressures from the EU and IFIs to legitimize privatization and structural adjustment as unavoidable responses to the demands of globalization.Privatizations of public sectors are used to legitimize appropriation of public assets by ruling elites and their families and cronies, thereby turning public into private monopolies. In the process, ruling coalitions are re-structured, with older populist (labour and peasant) constituencies now marginalized. Democratization is deterred because the masses that pay the cost of these policies could be empowered by it, threatening both regimes and crony capitalists (Guazzone and Pioppi 2009). 
Reflective of the reality of crony capitalism, there was no improvement in economic freedom indices in the MENA states over the first ten years of the EMP. In a sense the EU has helped, together with neo-liberal globalization, to reconstitute the MENA states as more exclusive post-populist forms of authoritarianism that are not readily compatible with the liberal practices the EU seeks to export (Kienle 1998). Furthermore, especially since 9/11 and the bombings in London and Madrid, the stress has shifted to security cooperation with southern Mediterranean regimes against the shared "terrorist" threat from radical Islamists, a stance most obvious in the Algerian case despite rhetorical insistence that political reform is needed to attack the roots of terrorism (Seeberg 2010: 299-300).

The cultural dimension of the EMP has also failed to drive a "convergence of civilizations." Certain dialogues were set in motion and at the civil society level transnational interaction between NGOs developed; but these largely excluded Islamist groups and even Arab liberals were reluctant to engage closely. The securitization of immigration issues damages Europe's image and restricts freedom of movement within the imagined Mediterranean community. Culture wars also blighted relations: the Danish cartoon fiasco inflamed opinion on both sides. Europe does not practice its liberal values, as MENA publics see it, as it moves to ban headscarfs and mosque or minaret building. One Saudi columnist considered Europe's simultaneous tolerance of female nudity and intolerance of the veil as breathtaking hypocrisy (Syed 2010). Europe is pulled between anti-immigrant and Islamophobic sentiment on the right and on the left demands for humanitarian interventions seen by MENA states as threats to sovereignty, e.g., in support of the Iraqi Kurds after the Gulf war or in Dhafur (Salame 1998, Joffe 1998). The success of political cooperation among the partnership countries was predicated on the resolution of the Arab-Israeli conflict expected in the wake of the Oslo Accord but, according to Aliboni (2010), the failure of the peace process blocked such cooperation.

The EMP is also criticized for its institutional asymmetry. The EU dominates the partnership, with the European side always taking the initiative; it is managed by the European commission rather than a joint institution with the MENA states (Albioni et. al. 2008; Vasconcelos and Cardoso Reis 2002). MENA states are simply expected to adhere to EU-imposed standards and practices at the expense of their sovereignty. The Union of the Mediterranean, launched in July 2008, was intended to revive the Barcelona process. Complaints that the relation was not a true partnership were to be addressed, for example, by creating a dual rotating presidency and a jointly appointed secretariat. Collaboration on specific practical projects would be jointly selected by the partners (Aliboni et. al 2008). This was, however, a minimalist project reflecting a significant lowering of expectations about the "Barcelona process."

\section{Four Hard Cases}

Four cases illustrate the dilemmas, impotence or double standards of European MENA policy, caught, as it is, between the US and the region and by its own ambivalence toward its regional "partners."These cases also help explain the parallel ambivalence of MENA countries toward Europe.

\subsection{Europe and the Arab-Israeli Conflict}

From the start, EU-Arab relations were shaped by the Arab-Israeli conflict. The Euro-Arab Dialogue was precipitated by the oil embargo and energy crisis growing out of the 1973 Arab-Israeli war. In this, the Europeans proposed energy security in exchange for economic and technical cooperation, but the Arab side wanted to use its new oil power to extract political support in the Arab-Israeli conflict; Europe, however, could not diverge very far from US positions. The legitimacy of the PLO, denied by the US, was a particular point of contention, but in 1980the EU did endorse Palestinian national self-determination (Baabood 2010). After the 1993 Oslo agreement, the EU became the largest donor to the Palestinian Authority (PA) created under it and accorded the Palestinian territories separate quotas for agricultural exports to Europe. The EU blamed Israeli settlements for the breakdown of the peace process and did not follow the US in cutting off aid to the PA after the second intifada; it did however become more preoccupied with corruption inside the PA than with the measures taken by Israel that were likely to make PA governance impossible. Many Europeans were antagonized by the Israeli destruction of EU funded projects in the Palestinian territories. The EU criticized the "Security Wall" and the Gaza blockade (which it considered collective punishment), and, despite intense lobbying by Jewish groups, the European Parliament endorsed the Goldstone Report that accused Israel of war crimes in the Gaza war of 2008. But, although Tel Aviv largely ignored European criticism, the EU refrained from using its potential trade leverage over Israel, which depends on exports to Europe, to overcome its intransigence except for some delays in approving trade arrangements and a ruling by the European Court of Justice that Israel cannot export under the EU-Israel partnership agreement products made by settlers on occupied Palestinian land. The EU explicitly declined to link the bestowing of the EMP's social and economic benefits to parties' respective 
positions towards the peace process (Youngs 2003). Any criticism of Israel is silenced on the ground that its confidence must be retained to forward the peace process, but its actions systematically obstruct that process. Ironically, Israel is accorded a more "advanced" relation with the EU ostensibly made on the basis of its convergence toward rule of law and respect for international law.

The EU, having insufficient leverage over the parties to the conflict, has accepted US dominance of the issue (Asseberg and Salem 2009). While Europe pays higher costs than the US from the on-going conflict, whether in terms of energy prices, refugees, alienation of Muslim citizens and terrorism, the US alone has the influence over Israel to resolve the conflict, which, however, it does not use. The EU joined the Quartet, sponsored by US President George W Bush, that was supposed to lay out a "road map" to peace but which predictably stalled (Seeberg 2010). It followed the US in listing Hamas as a terrorist movement and when it won the Palestinian elections participated in the US isolation of the new Palestinian government. Naturally this undermines European credibility in the Arab world.

\subsection{The US-EU-Iran Triangle}

Iran under Khomeini saw the US as the "Great Satan" but France and Britain were also seen as conniving at Iraq's 1980 invasion by not demanding an Iraqi withdrawal in the Security Council and also by supplying arms to Iraq and sending naval ships to the Gulf. But with the end of the Iran-Iraq war and the rise of the pragmatic Rafsanjani presidency, Iran began a strategic opening to Europe that would have made it Iran's source of capital and technology in place of its pre-revolutionary partnership with the US. With the 1989 Rushdi fatwa issue sidelined, the hostage crisis in Lebanon resolved and Iran's perceived responsible behaviour in the Gulf war, Iranian-European relations improved, although the murders of Iranian exiles periodically set back their full normalization. Attractive to the EU as one of the few Gulf countries not under US dominance, Iran became a site of EU-US rivalry. In response to Iranian courting of external investment, Germany took the lead in developing economic ties with Iran against US objections, acquiring $26 \%$ of Iran's import market. US policy to isolate Iran diverged from Europe's "critical" (later "constructive") dialogue/engagement in which, especially after President Khatemi came to power in 1997, Europe aimed to strengthen Iran's reformists as a way of bringing Iran into conformity with "international norms." Europe's dialogue with Tehran on human rights facilitated the passage of human rights and women's rights bills in the majlis. The divergence with Washington deepened when pressure from the Zionist lobby brought the US government to force the US oil company, Conoco, to disinvest from Iran and France's Total took up the contract. European energy imports from Iran soared. This led to EU-US confrontation over the Iran-Libya Sanctions Act, an attempt to force Europe out of Iran, whose extra-territorial provisions Europe considered illegal; although the US backed off, as Europe threatened retaliation and prepared to take the issue to the WTO, US sanctions still constrained Europe's economic relations with Iran, blocking, for example, the sale of airbuses that had US components. After September 11 and Bush's spurning of the Iranian reformists' offer of détente, in spite of Iran's cooperation in the war on the Afghan Taliban, Khatemi sought protection in closer relations with the EU. In response to Bush's inclusion of Iran in his "Axis of Evil" and against the Clash of Civilizations thesis, Khatemi proposed a Dialogue of Civilizations in which each would respect and learn from each other. Iran, France and Germany agreed in opposing the 2003 US war on Iraq. The $\mathrm{EU}$, under its soft-power strategy, offered Iran a trade and cooperation agreement conditional on political and judicial changes, in parallel to Khatemi's own soft power initiative.

In 2003, however, the US raised the nuclear issue after revelations that Iran was enriching uranium and sought to get Iran referred from the IAEA to the Security Council for sanctions; Europe tried to head this off through the tripartite (EU3) mission to Iran which persuaded Iran to accept the NPT Additional Protocol,(allowing short notice inspections) and to suspend uranium enrichment. The agreement broke down in part because the EU could not broker delivery of security assurances to Iran from the US. After February 2004, when, partly in consequence of the growing external pressures on Iran, hard-line conservatives won a majority in the Iranian parliament, the EU's engagement with Iran lost its momentum. Bush's axis of evil speech further facilitated the June 2005 election of hardliner Mahmoud Ahmadinejad, after which the EU decided to sacrifice its Iran relations to mend frayed relations with Washington. In parallel, Iran abandoned its Eurocentric strategy in favour of relations with Russia and China. The nuclear issue then went to the UN Security Council with the backing of the $\mathrm{EU}$, starting the imposition of sanctions. As Iran remained defiant in the face of successive waves of sanctions, Europe began breaking its economic links to the country. In 2010 EU sanctions, going beyond UN-mandated ones, included a ban on new investment and technology transfers to Iran's gas and oil industry. As with Iraq, the US had constructed "security threats" to block its economic rivals from pre-empting a major hydrocarbon market that it had denied its own companies. Inside Iran, Ahmadinejad faced growing opposition climaxing in the contesting election of 2009 and the subsequent widespread protests; his main ideological defence was to 
stigmatize the opposition as agents of the West, consolidating his hard line constituency amidst conflict with the West and benefiting from the dominant view in Iran that the West sought to unfairly single out and deprive Iran of nuclear technology. The hardliners in Washington and Tehran had empowered each other, squeezing out moderate voices in both West and East (Drenou 2008; Sabet-Saeidi 2008, Moshaver 2005, Kaussler 2008; Youngs 2004: 14).

\subsection{Syria: the Education of Bashar Al-Asad}

The saga of the negotiations over Syria's accession to the EMP further illustrates the problematic engagement between Europe and MENA. The seemingly shared belief in the efficacy of economic liberalization by both the EU and new Syrian president, Bashar al-Asad, provided the backdrop to the negotiations. European representatives in Damascus claimed the EU 'seeks to engage countries through dialogue, forsaking the colonial mentality with which others [the US] approach the region' (Cavatorta and Arana 2010). Asad looked to the EU as a model and a facilitator of economic modernization within, expecting to use the agreement's provisions to overcome entrenched domestic opposition to it. All through this period, the EU funded projects facilitating reform e.g. in the administration, banking, education and infrastructure.

Parallel to Bashar al-Asad's growing conflict with the US over the invasion of Iraq, he also saw an association agreement with Europe as an urgent buffer against US hostility. But EU negotiators took advantage of this to make unprecedented demands for internal economic liberalization, an inequitable arrangement that would be more damaging than beneficial for Syria. The EU rebuffed Syrian wishes for restrictions on investment and currency freedom of movement; for a transition period in application of intellectual property rights, and for continuance of some tariff protection and the right to prohibit certain imports (Hinnebusch 2003). As Zorob (2009) pointed out, the Syrian-European Association Agreement was the only one that provided for such an unqualified opening of a MENA state's economy. The episode is evidence that the EU is by no means above exploiting power asymmetries with its so-called partners in MENA.Even so, Syria signed the protocol but the EU, adopting US concerns, tried to make it contingent on grossly unfair and unprecedented demands regarding non-conventional weapons (that, not applying to Israel, implied unilateral disarmament of Syria's non-conventional deterrent).

After Syria was accused of involvement in the assassination of Lebanese Prime Minister Hariri the partnership agreement was frozen and relations deteriorated; the EU explicitly used the withholding of the agreement as a stick to try to change Syria's foreign policy, such as its support for Hizbollah and its role in Lebanon. Indeed, Syrian-EU relations were now played out in a struggle for Lebanon, with the coup d' force of Hizbollah in Beirut in 2008 making it clear that Syria could not be isolated. Thereafter, French President Sarkozy's controversial invitation to Bashar to the launch of his Mediterranean Union broke the wall of isolation around Syria that the US and former President Chirac had erected. Sarkozy calculated that engagement was more likely to secure Syrian cooperation in stabilizing Lebanon and that Syria's isolation had only pushed it into greater alignment with Iran.Pressures for democratization and human rights were restrained since Bashar's regime was seen as much preferable to the likely Islamist alternative. Syria's association agreement was revived but, once relieved of the immediate US threat, Syrian economic managers became more sensitive to the economic costs and delayed its ratification; instead Syria sought to pursue its economic modernization in tandem with Turkey, which welcomed deepening economic relations while rejecting Western demands to isolate Syria. Inside Syria, the partnership episode had demonstrated that the West still sought to dominate the region and that economic relations with it would be made conditional on satisfying Western political interests. While many Syrians welcomed EU pressures on the Syrian government over human rights, most Syrians also widely perceived Western pressures on Syria as mostly designed to force abandonment of its nationalist foreign policy in the struggle with Israel.

\subsection{Spurned Suitor: the Case of Turkey}

Turkey has long been the most Eurocentric of the MENA states but relations with Europe have cooled. The ruling AKP government came to power in 2002,committed to pursuing Turkish membership in the EU. It had reason to feel gratitude toward the EU whose disapproval of military intervention against elected Islamist politicians had become a constraint on the military as long as the Turkish establishment pursued its avocation of EU membership. The AKP legislated the political reforms Europe expected and deepened economic integration with Europe. In 2004 it accepted the Annan plan on Cyprus and actively worked to get Turkish Cypriots to approve the deal against the opposition of the hard-line Turkish Cypriot leader. Yet, as of 2004-2005, Turkey's accession appeared less likely because of French and German opposition to it, and because of the Greek Cypriot vote against the Annan Plan on island unification, as a result of which Turkey has refused to open its ports and 
airspace to Nicosia until it ended its embargo against Turkish northern Cyprus. Nicosia, now inside the EU, engineered, with French support, a suspension of Turkey's accession process. The EU had, as Robins (2007) argued, broken one of its own rules in allowing the accession of the Greek part of Cyprus before settlement of the island's conflict, "importing Cypriot instability" rather than exporting its security community to Cyprus. Although France had applauded Turkey for its "European-ness" in resisting US pressures to join in the 2003 war on Iraq, French politicians now professed to see Turkey as alien to Europe.

The frustration in Turkey over its on-again, off-again membership negotiations with the European Union is reflected in the decline of Turkish respondents having a favorable view of the EU from $58 \%$ in 2004 to $22 \%$ in 2007. Ankara has moved to balance relations with Europe with new ties to MENA (Aliboni 2010; Turkes 2007). Precipitated in part by the chaos unleashed by the US war on Iraq, Turkey has tried to secure its borders by consciously adopting EU-like "soft security" approaches to its MENA neighbours, in pursuit of which it declined, unlike Europe, to follow Washington's demonization of Syria, Iran and Hamas. Thus, when the EU, under US pressure, made recognition of the elected Hamas government conditional on its recognition of Israel, Turkey argued that the results of democratic elections should be respected; Turkey also explicitly declined to follow their drive to isolate Syria over the Hariri murder. Turkey promoted itself as a bridge between the EU and MENA, a status that, in the long run, it believed increased its value to both (Kibaroglu and Oguzlu 2008). This Turkish stance met with widespread approbation in Arab public opinion, where the old cleavage of Turkish and Arab nationalist discourses was giving way to a shared appreciation of the Ottoman period and an Arab hope that Turkey could become a bulwark against Western neo-imperialism in the region. Turkey's ambition to bridge the regions, by bringing the Middle East into the EU (via its membership) and bringing Europe to MENA via export of its own model, is pregnant with possibilities for the clash or convergence of civilizations.

\section{Elite and Public Opinion: Clash or Convergence of Civilizations?}

In spite of the European origins of many of the current problems of the Middle East, regional opinion has seen Europe as benign compared to the US. People view other countries in terms of how they threat their own country, but for the Arabs, their "country" is the broader Arab world, not the individual state in which they live; as such, publics views of other states has been predominantly shaped by their concerns about Palestine and Iraq. After the US and Israel, US partner Britain is the third least liked country in Arab opinion due to its alignment with the US on these issues. Most highly favourable attitudes in the Arab world were toward France, with President Chirac being at one point one of the most popular world leaders in the region, a function of French opposition to US policies (Furia and Lucas 2006; Telhami 2006).

Surveys and analyses of the regional press reveal a desire for the EU, seen as more even-handed on the Arab-Israeli conflict (while Israel sees Europe as biased against it), to play a balancing role against the US and to facilitate the Arab-Israeli peace process. But there was widespread frustration at the ineffectiveness of the EU in this respect. Thus, the Union for the Mediterranean project was regarded with suspicion in regional opinion as a mechanism to normalize Arab-Israeli relations (by bringing Israel and the Arab states into a common framework) without resolving the Palestine issue (Seeberg 2010: 296-8). In regard to European immigration policy, the Middle East sees double standards at work, with the EU defending freedom of circulation for capital - Northern investment in the South - but restricting the movement of Southern agricultural goods and workers towards the North. Some members of radical Islamist movements see Europe as part of a Western world that is essentially hostile (Vasconcelos and Cardoso Reis 2002).

The EU's regional image has declined as its policies have converged with those of the US. In the 2009 Pew Global Affairs survey, in contrast to every other global region, negative views of the EU were expressed by large majorities in Jordan (72\%), Turkey (59\%), the Palestinian territories (57\%), and Egypt (50\%). Confidence in European leaders was also uniquely low in MENA compared to other regions. (http://pewglobal.org/reports/pdf/264.pdf). What also makes Europe's alignment with the US costly is America's increasing unpopularity with the some 12 million European Muslims who have become a factor in domestic politics and tiny numbers of which have used terrorism to contest Europe's involvement in American MENA policy. However, views differ between MENA elites and wider publics, reflective of the uneven impact of Europe's neo-liberal policies: thus, a 2008 survey in Jordan found 58\% of élites had a positive view of the EU's assistance in privatization while a majority of ordinary people saw it as having failed to address unemployment, inequality and poverty, reflective of the deleterious effects of privatization on them.

Optimism regarding EU-MENA relations has declined since the Barcelona accord. In a 2009 Survey of Experts on both sides of the Mediterranean, $73 \%$ of respondents saw the EMP as endangered by the Arab-Israeli conflict, with two-thirds wishing the EU would undertake a peace initiative but not expecting it. The EMP was seen as 
improving the business climate without translating into jobs or reducing inequality in MENA. Only 20\% believed a common Mediterranean identity would emerge. According to Idriss (2010), among activists, intellectuals and NGOS in the region "double standards" is the term commonly used to describe EU policies in the Middle East.Europe is seen as no more serious about democracy than the US; rather democratization is a rhetorical tool selectively applied against regimes that defy the West: thus, rigged elections are accepted in Egypt and Algeria and condemned in Iran and a fair election in the Palestinian territories is rejected. This is widely seen as reflecting a preferential treatment of regimes that are friendly with Israel or in which Europe has oil interests.

Europe's post 9/11 move toward greater concern with hard security has not gone unnoticed in MENA. The war on terror dictated security cooperation with authoritarian regimes while the perceived threat of proliferation of ballistic missiles and nuclear weapons in MENA translated into expenditure of political capital to get southern partners to adhere to arms control agreements and cooperation with the US on a missile defense system over the Mediterranean (Youngs 2003).The reconstruction of NATO to involve the US and Europe in interventions in MENA, actualized in Afghanistan, has not helped. Compared to the US "bad cop," Europe may still appear to be the "good cop," but Europe's remaining "soft power" appears at risk owing to its involvement in such coercive "policing" in MENA.

Indeed, Britain and France's 2011 intervention in Libya seemed to express a desire to addto a hard power dimension to Europe's soft power via American-style regime change--air bombing at little risk of casualties for their own forces but substantial "collateral damage" in the target society. These states, also like the Americans (in Iraq), managed to revenge themselves on an old anti-Western enemy and seemed likely to reap ample hydrocarbon spoils and install a friendly regime. Yet, they appear less likely than the US to pay costs in Arab public opinion, having seemingly been able to construct their intervention as "humanitarian" and on behalf of "freedom" (after France's having sided with the fallen regime in the Tunisian uprising).It is too soon to assess the longer-term consequences of the Libyan intervention for Europe's standing in MENA. But its new interventionism, effectively exploiting the cleavages of a MENA society, recalls similar practices in the late Ottoman and imperial periods.

\section{Conclusion}

Britain and France exported the Westphalian states system to the Middle East but in a flawed form that had conflict and instability built into it. Middle East peoples saw the West as both a threat and a model that needed to be selectively imitated in order to defend the region against Western expansion and, once the region was conquered, to empower resistance and enable viable independence. As Europe shed its imperial past, the US assumed the role of world hegemon, deploying hard power to contain Middle East conflicts and to establish control over the region's oil, which helped sustain its hegemony over Europe. Europe sought, thru the EMP, to export its experience of economic integration and democratization as an alternative solution to MENA's instability; EU norms were thought to also serve security purposes (Youngs 2004). EU discourse was much more respectful of MENA sensibilities and was welcomed by elites seeking to integrate into the world capitalist economy on favorable terms and intellectuals who hoped it would encourage democratization. In practice, the EMP aimed less at partnership than at assimilation of the south to the neo-liberal practices of the north, thereby promoting the reconstruction of the hub and spokes structure typical of the imperial era. As Adler and Crawford (2004) concluded, the Barcelona Process was caught between the language of post-colonialism and the behavior of neo-colonialism. Increasingly, too, Europe became a partner in the project of US hegemony over the region in which its soft power supplemented the American hard power directed at those who resisted this project. The actual outcome is to reincorporate the MENA region into a subordinate position in a global hierarchy that, as Little and Buzan (2009) observed, is incongruent with the norm of sovereign equality exported with the Westphalian states system at de-colonization.

Similar to the time of MENA's original historic encounter with the West, regional opinion remains focused on the unequal relations between East and West, with divisions in the region as to how the area should respond quite similar to that seen in the earlier period. As then, the region seeks to selectively adopt and reject Western practices. Attitudes, however, vary between elites and masses: at the elite level, contemporary versions of the earlier Westernizers have been empowered by the West's export of neo-liberalismwhile various forms of Islamism and nationalism predominate in civil society. What elites and masses share is a thorough internalization of the Westphalian norms of sovereignty and national self-determination for the region. The crux of the current tensions between Europe and MENA is that while the latter still struggles to actualize its sovereignty, Europe has "moved on," becoming an agent of the neo-liberal globalization that threatens this sovereignty. 


\section{References}

Adelson, R. (1995). London and the Invention of the Middle East: money, power and war, 1902-1922. Yale University Press.

Adler, E., \& Crawford, B. (2004). Normative Power: The European Practice of Region Building and the Case of the Euro-Mediterranean Partnership (EMP). Berkeley, Institute of European Studies, University of California. Retrieved from http://www.escholarship.org/uc/item/6xx6n5p4

Alibon, R. (2010). The Mediterranean and the Middle East: Narrowing Gaps in Transatlantic Perspective. Washington, DC: German Marshall Fund, Mediterranean Paper Series, March.

Aliboni, R. (2008). Union for the Mediterranean: Building on the Barcelona Acquis. European Union Institute for Security Studies (no. 1).

Alnasrawi, A. (1991). Arab Nationalism, Oil and the Political Economy of Dependency. New York and London: Greenwood Press.

Asseburg, M., \& Salem, P. (2009). No Euro-Mediterranean Community without Peace (pp. 13-27). Paris/Brussels: The EU Institute for Security Studies and the European Institute of the Mediterranean-IEMed.

Baabood, A. (2010). What an effective Arab strategy for the EU should look like. Europe's World. Retrieved from

http://www.europesworld.org/NewEnglish/Home_old/Article/tabid/191/ArticleType/ArticleView/ArticleID /21591/WhataneffectiveArabstrategyfortheEUshouldlooklike.aspx

Brown, L. C. (1984). International Politics and the Middle East: Old Rules, Dangerous Game. Princeton, NJ: Princeton University Press.

Buzan, B. (1991). New patterns of global security in the twentieth-first century. International Affairs, 67(3), 246-247. http://dx.doi.org/10.2307/2621945

Cavatorta, F., \& Vincent, D. (2010). The Foreign Policies of the European Union and the United States in North Africa: Diverging or Converging Dynamics. London and NY: Routledge.

Cavatorta, F., \& Arantza, G. A. (2011). The European Union's critical engagement with the Syrian Arab Republic.European Foreign Affairs Review.

Clark, I. (2001). Another double movement; the great transformation after the Cold War. In M. Cox, T. Dunne, \& K. Booth. Empires, Systems and States: Great transformations in international politics (pp. 237-255). Cambridge.

Dostal, J. M. (2009). The European Union and Economic Reform in Syria. In J. M. Dostal, \& A. Zorob, Syria and the Euro-Mediterranean Relationship. St Andrews: Center for Syrian Studies and Boulder, CO: Lynne Rienner Publishers.

Drenou, A. (2008). Iran: Caught Between European Union-United States Rivalry?. In Ehteshami, \& Zweiri, Iran's Foreign Policy (pp. 73-87).

Ehteshami, A., \& Mahjoob, Z. (2008). Iran's Foreign Policy: From Khatami to Ahmadinejad. Reading, UK: Ithaca Press.

Euractiv. (2007). Geopolitics of EU energy supply. Retrieved from http://www.euractiv.com/en/energy/geopolitics-eu-energy-supply/article-142665

Eurostat. (2009). EuroMediterranean Statistics. Brussels: European Commission.

Fromkin, D. (1989). A Peace to End All Peace; the Fall of the Ottoman Empire and the Creation of the Modern Middle East. New York: Avon Books.

Furia, P., \& Lucas, R. (2006). Determinants of Arab Public Opinion on Foreign Relations. International Studies Quarterly, 50, 585-605. http://dx.doi.org/10.2307/2621945

Grahl, J. (2004). The European Union and American Power. In L. Panitch, \& C. Leys (eds.), The Empire Reloaded (pp. 284-300). Merlin Press.

Guazzone, L., \& Pioppi, D. (2009). The Arab State and neo-liberal Globalization: the restructuring of the state in the Middle East. Reading, UK: Ithaca Press. 
Halliday, F. (1998). Western Europe and the Iranian Revolution, 1979-97. The Middle East and Europe, 130-150.

Hinnebusch, R. (2003). Syrian Foreign Policy between Regional Conflict and European Partnership. Review of International Affairs, 3, 1-16. http://dx.doi.org/10.2307/2621945

Holden, P. (2010). Security, power or profit? The economic diplomacy of the US and the EU in North Africa. In F. Cavatorta, \& V. Durac, The Foreign Policies of the European Union and the United states in North Africa: Diverging or Converging Dynamics (pp. 10-31). London and NY: Routledge.

Hollis, R. (1997). Europe and the Middle East, Power by Stealth?. International Affairs, 73(1), 16. http://dx.doi. org/10.2307/2623548

Hollis, R. (2009). Europe in the Middle East. In L. Fawcett (Eds.),International Relations of the Middle East (pp. 331-348). Oxford and NY: Oxford University Press.

Hourani, A. (1962). Arabic Thought in the Liberal Age, 1789-1939. Oxford University Press.

Hourani, H., \& May. A. (2008). Perceptions of European Union action in Jordan, New Jordan Research Center. Retrieved from http://www.ujrc-jordan.org/pdf/Perceptions\%20of\%20EU\%20action\%20in\%20Jordan.pdf

Hyde-Price, A. (2006). Normative power Europe: a realist critique. Journal of European Public Policy, 13, 217-234. http://dx.doi.org/10.1080/13501760500451634

Idriss, A. (2010). Europe and democracy in the wider Middle East. Retrieved from http://www.europesworld.org

Joffe, G. (1994). Relations between the Middle East and the West: a view from the South. In B. A. Roberson, The Middle East and Europe: the power deficit (pp. 45-73), London and New York: Routledge.

Kaussler, B. (2008). European Union Constructive Engagement with Iran (2000-2004): An Exercise in Conditional Human Rights Diplomacy. Iranian Studies, $41(3)$. http://dx.doi.org/10.1080/00210860801981237

Khalidi, R. (2004). Resurrecting Empire: Western footprints and America's Perilous Path in theMiddle East. I. B. Tauris.

Kibaroglu. M., \& Oguzlu, T. (2008). Incompatibilities in Turkish and European Security Cultures Diminish Turkey's prospects for EU Membership. Middle Eastern Studies, 44(6), 945-962. http://dx.doi.org/10.1080/00263200802426229

Kienle, E. (1998). Destabilization through Partnership? Euro-Mediterranean Relations after the Barcelona Declaration. Mediterranean Politics, 3(2), 1-20. http://dx.doi.org/10.1080/13629399808414651

Little, R., \& Buzan, B. (2009). The Historical Expansion of International Society. ISA's Annual Convention, NY. Retrieved from http://www.allacademic.com/meta/p311704_index.html

Lustik, I. (1997). The Absence of Middle Eastern Great Powers: Political 'Backwardness' in Historical Perspective. International Organization, 51(4), 653-683.

Manners, I. (2002). Normative Power Europe: A Contradiction in Terms?. Journal of Common Market Studies, 40, 235-258. http://dx.doi.org/10.1111/1468-5965.00353

Marks, J. (1998). High Hopes and Low Motives: The New Euro-Mediterranean Partnership Initiative. Mediterranean Politics, 1(1), 1-24.

Marr, P. (1998). The United States, Europe and the Middle East, In B. A. Roberson, The Middle East and Europe: the power deficit (pp. 74-104). London and New York: Routledge. http://dx.doi.org/10.1080/13629399608414564

Michalek, J. (2005). Economics in the Mediterranean: Common Challenges. In A. Marchetti (Eds.), Ten Years of Euro-Mediterranean Partnership (pp. 59-81). Bonn: Center for European Integration Studies, Rheinische Friedrich-Wilhelms-Universität.

Miller, R., \& Mishraf, A. (2005). The Barcelona Process and Euro-Arab Economic Relations: 1995-2005. Middle East Review of International Affairs, 9(2).

Moshaver, Z. (2005). Revolution, Theocratic Leadership and Iran's Foreign Policy: Implications for Iran-EU Relations. In G. Nonneman (Eds.), Analyzing Middle East Foreign Policies and the Relationship with Europe (pp. 174-196). London and New York: Routledge. 
Nienhaus, V. (1999). Promoting Development through a Euro-Mediterranean Free Trade Zone?. European Foreign Affairs Review, 4, 501-518.

Nonneman, G. (2005). The Three environments of Middle East Foreign Policy Making and Relations with Europe. Analyzing Middle East Foreign Policies and the Relationship with Europe (pp. 19-42). London: Routledge.

Owen, R. (1981). The Middle East in the world economy, 1800-1914. London and N.Y.: Meuthen.

Parfitt, T. (1997). Europe's Mediterranean Designs: An Analysis of the Euromed Partnership with Special Reference to Egypt. Third World Quarterly, 18(5), 865-881. http://dx.doi.org/10.1080/01436599714632

Roberson, B. A. (Eds.) (1998). The Middle East and Europe: the power deficit. London and NY: Routledge.

Robins, P. (2007). Between the EU and the Middle East: Turkish Foreign Policy under the AKP Government, 2002-2007. Milan: Instituto Per GliStudi di PoliticiaInternazionale.

Sabet-Saeidi, S. (2008). Iranian-European Relations: A Strategic Partnership?. In Ehteshami \& Zweiri, Iran's Foreign Policy (pp. 55-72).

Salame, G. (1998). Torn between the Atlantic and the Mediterranean: Europe and the Middle East in the post-Cold War era. In B. A. Roberson, The Middle East and Europe: the power deficit (pp. 20-44), London and New York: Routledge.

Schumacher, T. (2004). Survival of the Fittest: the First Five Years of Euro-Mediterranean Economic Cooperation. EUI-RSCAS Working Paper, No. 14, BadiaFiesolana.

Schumacher, T. (2010). Transatlantic Cooperation in the Middle East and North Africa and the Growing Role of the Gulf States. Washington, D.C.: German Marshall Fund, Mediterranean Paper Series, July.

Seeberg, P. (2010). Union for the Mediterranean - Pragmatic Multilateralism and the Depoliticization of $\begin{array}{lllll}\text { EU-Middle Eastern } & \text { Relations.Middle } & \text { East } & \text { Critique, } & 19(3),\end{array}$ http://dx.doi.org/10.1080/19436149.2010.514477

Spiro, D. E. (1999). The Hidden Hand of American Hegemony: Petrodollar Recycling and International Markets. Ithaca and London: Cornell University Press.

Syed, A. Z. (2010). The Muslims Are Coming!! Arab News (Saudi Arabia), May 7.

Telhami, S. (2006). Annual Arab Opinion Survey. University of Maryland/Zogby International.

Tonra, B., \& Francesco, C. (2007). Normative Foundations in the EU Foreign, Security and Defence Policy: The case of the Middle East Peace Process. Contemporary Politics, 42(4), 731-756.

Turkes, M. (2007). Cycles of Transformation of the Cyprus Question. In N. A. Guney, Contentious Issues of Security and the Future of Turkey (pp. 159-176). Aldershot, UK: Ashgate.

Valbjørn, M. (2011). Culture in the Middle East: the 'Western Question' and the sovereignty of post-imperial states in the Middle East. In S. Cummings, \& R. Hinnebusch (eds.), Sovereignty after Empire: Comparing the Middle East and Central Asia. Edinburgh: Edinburgh University Press.

Vasconcelos, A., \& Cardoso, R. B. (2002). European Defence - Perceptions vs. Realities (Vol. 16, 14-22). Lisbon: IEEI, EuroMeSCo Paper.

Youngs, R. (2003). European Approaches to Security in the Mediterranean. MiddleEast Journal, 57(3), 414-431.

Youngs, R. (2004). Normative Dynamics and Strategic Interests in the EU's External Identity. Journal of Common Market Studies, 42(2), 415-435.

Zorob, A. (2008). Trade Liberalization and Adjustment via Regional Integration: The Syrian-European Association Agreement. Syria and the Euro-Mediterranean Relationship. St. Andrews Papers on Contemporary Syria, Boulder, CO: Lynne Rienner Publishers. 